
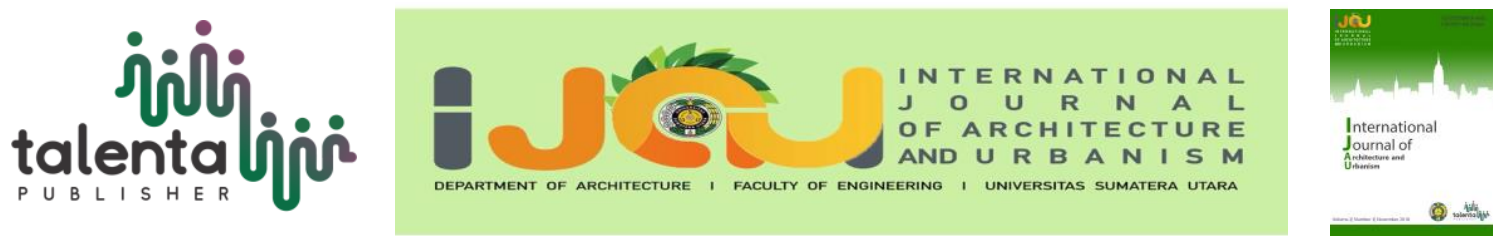

\title{
Islamic Bathroom: A Recommendation of Bathroom Layout Design with Islamic Values
}

\author{
Rahmadhani Novi ${ }^{1 *}$, Hamid M Irfan M P2 \\ ${ }^{1}$ Architecture Department, Faculty of Engineering Universitas Sumatera Utara,Medan, Indonesia \\ ${ }^{2}$ Indonesian Institute of Architects, Medan, Indonesia
}

\begin{abstract}
A bathroom is a room that cannot be separated from humans' daily lives and there are activities performed inside of it. Today's bathroom usually is designed in the universal style, even though there is no human with the same background nor the same religion. Every religion has its own rules and should be applied by its followers in every aspect of their lives, especially in Islam. There are two guidelines which have the explanation of the bathroom etiquette, Al Quran and Hadits. For the Muslim users, the synchronization between bathroom etiquette and the design of the bathroom is an effort of the observance to Allah SWT. Therefore, this writing is an attempt to give a reminder and also a recommendation of bathroom design layouts based on the rules of Islamic bathroom etiquette. The methodology of this research is to describe all of the bathroom etiquettes in Al-Quran and Hadits and make the concept of the bathroom design layouts based on what is permitted and forbidden.
\end{abstract}

Keyword: Architecture, bathroom, Islam, recommendation

\section{Introduction}

The word of Islam comes from the Arabian, from the Semitic trilateral words 'sin-lam-mim" $(\mathrm{S}-\mathrm{L}-\mathrm{M})$ rooted from the word Salam that means peace and joy and Aslama means to accept, to surrender. Therefore, a Muslim must have the character to obey the commands of God and stay away from all the prohibitions as the observance to achieve a peaceful and joyful life. Rules of Islam included in every aspect that delivered to the Prophet, Muhammad SAW as a revelation to complement the Akhlak /morals of all human beings. Islam believes that the Prophet, Muhammad SAW is the man with the best morals to be emulated. The revelation and the Akhlak of the Prophet recorded by the followers in two forms, those are Al-Quran and Hadits and guarded hereditary. Therefore the content of these guidelines of Islam will always valid and worth to be followed until the end of the time. Many religions have their own rules of designing a house, included the rooms in it, for example, the Feng Shui of the Buddhist, and the Vastu Shastra of the Hindus. In Islam, as mentioned before, the rules of every aspect of life has two guidelines, Al-Quran and Al-Hadits included the way of purification.

\footnotetext{
*Corresponding author at: Department of Architecture, Faculty of Engineering, Universitas Sumatera Utara,

Jalan Perpustakaan Gedung J07, Medan 20155, Indonesia

E-mail address: nrahmadhani@usu.ac.id
} 
According to history, the development of bathrooms is not for hygiene matters. One of the earliest baths originates from Hindus Valley in Pakistan, which was used for purification ritual before entering the holy place and usually used together, male and female. Greek and Roman had their public bathing in the city as an entertainment besides of purification ritual. Even if the king or queen or the noblemen didn't use it, they performed it in their houses, accompanied by their maids to help them cleansed their bodies, mostly for the ritual needs. When Islam came, there were new rules. Islam taught the limitation of seeing others' parts of the body for different gender or the same gender as well, except for the married couple, between the husband and the wife, it is not applicable. Therefore, the privacy of the bathroom was invented. Public bathing was diminished. Taking a bath or Ghusl in Arabian, defecating and urinating were all done alone, and there is a prohibition in Islam to linger the time when using the bathroom. What about the design?

The Prophet SAW never set the rule of a bathroom style. Today's bathroom is varied, combining stylish looks with functionality, fusing the illogical and logical issues. Designed as beautiful as it could, varied in color and hi-tech armatures. The International standard is a must! Aside from it can be functioned well, the users see everything aesthetically. Bathroom styles of today, ranging from the sleek and contemporary to the elegant and traditional. The products of fittings are competing to be the most economically reduce water usage. And once more, it's all about style, function, and comfort. But what is the purpose of making a good bathroom? Is it to make the users comfortable to use it? Proofing the quality of the designer? Getting the admiration of others?

What about the value? Another illogical aspect that often forgotten. Led by two academics at Oxford University, the $£ 1.9$ million cost study found that human thought processes were programmed to religious concepts. People who live in cities or highly developed countries seems less likely to have religious beliefs than those living more rural way of life, the researchers found. Value is thickly embraced in Eastern countries, somehow different in the Western, or countries with highly developed [7]. In the Buddha, for example, a bathroom is the room with the worst Feng Shui in the house. So the Buddhist commonly do some steps to make it better. The design process of a religious bathroom is more complicated than the one with the international style. There are many issues to be considered in the process before making a decision. Therefore, the value of both designs won't be the same. The results won't feel the same.

\section{Literature Review}

Hadits is the compilation of what the Prophet had done (known as Sunnah as well) as the directions of the followers to followed until today. There are regulations of some activities in the bathroom: (1) Self-cleansing (take a bath / Ghusl, and clean other parts of the body), (2) 
Defecating / Urinating and performing Istinja afterward, (3) Ablution / Wudhu. The writer will describe the rules in Hadits based on those activities above.

\section{Rules before Entering and Exiting the Bathroom}

From The Book on Purification, recorded by At Tirmidhi [4], Anas bin Malik, said: "When the Prophet entered the toilet he would say: 'O Allah Indeed I seek refuge in You." Shu'bah (one of the narrators) said: "Another time he said: 'I seek refuge in You from Al-Khubthi and AlKhabith. “

From the Book on Purification, recorded by At Tirmidhi [4], 'Aishah (may Allah be pleased with her) said: "When the Prophet would exit the toilet he would say: 'Ghufranak.' “

From the Book on Dress, recorded by Sahih Al Bukhari [2], 'Aishah (may Allah be pleased with her) said: "The Prophet used to like starting from the right in performing ablution, combing his hair and putting on his shoes." This (beginning from the right) is not confined to the three acts mentioned in this Hadits. Rasulullah, Please be upon him, began good things with the right. The basic rule is that all those things that reflect dignity and elegance the right is preferred. So when entering the bathroom, which has no elegance in it, left is preferred, and when exiting the bathroom, right is preferred.

\section{Rules of Defecating/Urinating and Performing Istinja}

From Jami at-Tirmidhi, The Book on Purification, Abdur Rahman bin Yazid said [4]: “They said to Salman, 'Your Prophet taught you about everything, even defecating?' So Salman said, 'Yes. He prohibited us from facing the Qiblah when defecating and urinating, performing Istinja with the right hand, using less than three stones for Istinja, and using dung or bones for Istinja."

From Sunan an-Nasa'I in the Book on Purification, narrated from Abu Hurairah [3]: that the Prophet (SAW) said: "This Ayah was revealed about the people of Quba: In it are men who love to purify themselves. And Allah loves those who make themselves pure (9:108). " He said: "They used water to perform Istinja so this Ayah was revealed about them." 
From Sunan An-Nasa'I, in the Book of Purification [3], narrated from Rasulullah SAW 's wife, Aishah Radhiallahu'anha said: "Whoever tells you that the Messenger of Allah SAW urinated standing up, do not believe him, for he would not urinate except while squatting."

\section{Rules of Self Cleansing}

From Sunan Ibn Majah in the Book of Purification and its Sunnah, Abu Sufyan said [6]: "Abu Ayyub Al-Ansari, Jabir bin Abdullah, and Anas bin Malik told me that when this Verse: "In it (the mosque) are men who love to clean and to purify themselves. And Allah loves those who make themselves clean and pure." was revealed, the Messenger of Allah said: 'O Ansar! Allah has praised you for your cleanliness. What is the nature of your cleanliness?' They said: 'We perform ablution for prayer and we take a bath to cleanse ourselves of impurity due to sexual activity, and we clean ourselves with water (after urinating). He said: 'This is what it is. So adhere to it."

From Sahih Al-Bukhari in the Book on Ablutions (Wudhu') [1], narrated by Hudhaifa: "Whenever the Prophet got up at night, he used to clean his mouth with Siwak."

From Sahih Muslim in the Book on Purification (Kitab Al-Taharah) [8], Anas reported: A time limit has been prescribed for us for clipping the mustache, cutting the nails, plucking hair under the armpits, shaving the pubes, that it should not be neglected for more than forty nights.

\section{Rules of Ablution (Wudu'):}

From Sunan Ibn Majah in the Book on Purification and its Sunnah [6], narrated from Ubayy bin Ka'ab that: The Messenger of Allah called for water and performed ablution one. He said: "This is the minimum requirement of ablution' or he said: 'The ablution of one who, if he does not perform this ablution, Allah will not accept his prayer." Then he performed ablution washing each part twice, and he said: 'This is the ablution of one who, if he performs it, Allah will give him two shares of reward." Then he performed ablution washing each part three times, and said: 'This is my ablution and the ablution of the Messengers who were sent before me."

\section{Methodology}

There are several stages of the method to afford the recommendation of the bathroom design layout. First, the writer collects all of the rules related to the etiquette in the bathroom, mostly in Hadits, analyze them to get the permitted values and avoid the forbidden ones as the ingredients to make the concept of the bathroom design layout. The analysis stage will consist of four mayor aspects, that are zoning and accessibility, privacy, water source and drainage, and also 
fittings. The concept stage will contain about the solution of the design layout based on what is forbidden and what is not, and will be described in those four mayor aspects as well.

\section{Result and Discussion}

\section{Analysis}

From the aspect of zoning and accessibility, there are three main activities in the bathroom and will be divided based on the need for cleanliness quality and how it can be accessed. Although these activities have the same purpose which is cleaning the impurity with the water, there's little difference in ablution. Ablution is performed before prayer, to 'meet' the God. So it needs the highest cleanliness level and should be placed far from the impurity sources to prevent the invalidation (Table 1).

Commonly the Muslim (the men) must perform their prayers in the Mosque and the women, Muslimah, are best perform their prayers in their bedrooms. In the privacy aspect, The same gender is allowed to do ablution together at the same time. There is a limitation of aurat applied for mature people that can't be seen by others, even with the same gender. The bath of junub needs privacy for married couples to perform. The wife and husband can do it together or separately, and it's best to separate the access from other users of the house to keep the couple's privacy. A master bathroom should be connected directly to the master bedroom if necessary. Defecating or urinating should only perform alone and needs high-quality privacy (Table 2).

Table 1. The analysis of zoning and cleanliness quality level

\begin{tabular}{|c|c|c|c|c|}
\hline No & Area & Activity Detail & Zoning Type & $\begin{array}{l}\text { Cleanliness } \\
\text { Quality Level }\end{array}$ \\
\hline \multirow[t]{5}{*}{1} & \multirow[t]{5}{*}{ Bath Area } & \multirow{2}{*}{$\begin{array}{l}\text { Perform daily once- } \\
\text { twice a day }\end{array}$} & Semi-Public & Medium \\
\hline & & & Accessed by family & \multirow{4}{*}{$\begin{array}{l}\text { The purpose of } \\
\text { this activity is to } \\
\text { cleanse the body. } \\
\text { If one gets } \\
\text { attached with the } \\
\text { impurities besides } \\
\text { menstruation or } \\
\text { junub (sexual } \\
\text { intercourse), then } \\
\text { there's no } \\
\text { invalidation }\end{array}$} \\
\hline & & $\begin{array}{l}\text { Perform after junub by } \\
\text { the married couple }\end{array}$ & $\begin{array}{l}\text { in couples (by the } \\
\text { husband and wife) }\end{array}$ & \\
\hline & & $\begin{array}{l}\text { Perform after } \\
\text { menstruation by } \\
\text { women }\end{array}$ & & \\
\hline & & $\begin{array}{l}\text { cleaning the hair of the } \\
\text { face and body, } \\
\text { brushing the teeth, } \\
\text { cutting the nail }\end{array}$ & & \\
\hline \multirow[t]{3}{*}{2} & \multirow[t]{3}{*}{ Ablution Area } & \multirow{2}{*}{$\begin{array}{l}\text { Perform before each } \\
\text { prayer }\end{array}$} & Public & High \\
\hline & & & $\begin{array}{l}\text { Can be accessed by } \\
\text { all family members }\end{array}$ & $\begin{array}{l}\text { The purpose of } \\
\text { this activity is to }\end{array}$ \\
\hline & & $\begin{array}{l}\text { Perform before going } \\
\text { to bed }\end{array}$ & $\begin{array}{l}\text { and can be seen by } \\
\text { other family }\end{array}$ & $\begin{array}{l}\text { cleanse parts of } \\
\text { the body, like }\end{array}$ \\
\hline
\end{tabular}




\begin{tabular}{|c|c|c|c|c|}
\hline & & $\begin{array}{l}\text { Perform when angry } \\
\text { Cleaning the hands, } \\
\text { face, mouth, nose, part } \\
\text { of the head, arms, ears, } \\
\text { feet, each in } 3 \text { times }\end{array}$ & $\begin{array}{l}\text { members (the ones } \\
\text { that connected by } \\
\text { blood called mahram, } \\
\text { can see some parts of } \\
\text { the body, ex: head, } \\
\text { hands, feet.) }\end{array}$ & $\begin{array}{l}\text { head, hands, } \\
\text { arms, and feet. } \\
\text { There are things } \\
\text { that can invalid an } \\
\text { ablution, impurity } \\
\text { such as urine, } \\
\text { feces, flatus, } \\
\text { madzi, jizz, } \\
\text { menstruation, } \\
\text { junub, etc }\end{array}$ \\
\hline \multirow[t]{4}{*}{3} & \multirow{4}{*}{$\begin{array}{l}\text { Defecating / } \\
\text { Urinating Area } \\
\text { (Toilet Area) }\end{array}$} & \multirow{2}{*}{$\begin{array}{l}\text { Perform when there is } \\
\text { a calling of nature }\end{array}$} & Private & Low \\
\hline & & & \multirow{3}{*}{$\begin{array}{l}\text { All family members } \\
\text { can access this area } \\
\text { in person. If } \\
\text { someone's inside, } \\
\text { nobody else is } \\
\text { allowed to enter }\end{array}$} & \multirow{3}{*}{$\begin{array}{l}\text { The purpose of } \\
\text { this activity is to } \\
\text { answer the call of } \\
\text { nature and } \\
\text { cleanse the } \\
\text { private area } \\
\text { afterward. There } \\
\text { is no invalidation } \\
\text { attached to this } \\
\text { activity. }\end{array}$} \\
\hline & & Perform alone & & \\
\hline & & $\begin{array}{l}\text { Perform istinja after } \\
\text { defecating /urinating } \\
\text { with flowing water } \\
\text { with the left hand }\end{array}$ & & \\
\hline
\end{tabular}

Table 2. The privacy quality level based on the activities

\begin{tabular}{cc}
\hline Activity & Privacy Quality Level \\
\hline $\begin{array}{c}\text { Taking a bath, clean any parts of the } \\
\text { body }\end{array}$ & Medium \\
\hline Ablution & Low \\
\hline Defecating / Urinating & High \\
\hline
\end{tabular}

Water is one of the cleaning media that mostly use for purification. A Muslim's bathroom should have a good water source to be used in ablution, bath, and Istinja. The best way to use the water is to use it frugally, and the layout should be set properly so the users can use it easily. The Muslim believes that the flowing water is the best way for doing purification. The flowing water cleanses the impurity from the body, and the water flow should be arranged well to prevent the used water from stagnating. Therefore taking a bath with bathtub doesn't recommend. The analysis of water quantity usage is in table 3.

Table 3. Water quantity usage based on activities

\begin{tabular}{cc}
\hline Activity & Water Quantity Usage \\
\hline Taking a bath, clean parts of the body & High \\
\hline Ablution & Medium \\
\hline Defecating / Urinating & Low \\
\hline
\end{tabular}


There are many types of fittings in the bathroom with varied design as well. Flowing water is the best way to purify the impurity in those three main activities. The choice of the fittings is according to the allowance of the Hadits (Table 4).

Table 4. Type of fittings based on what is permittable in Hadits

\begin{tabular}{cc}
\hline Activity & Type of Fittings Need \\
\hline Taking Bath & Shower, water tub, drain hole \\
\hline Ablution & Faucet, vessel, drain hole \\
\hline Defecating / Urinating & Toilet, bidet shower \\
\hline
\end{tabular}

\section{Concept}

The lobby is a transition place to recite the adhkaar before entering the bathroom and after exiting it. It also can be used to queued up when someone is using the toilet and as the preparation area / dry area. From the lobby, there can be access to the three main areas, or directly to the public. Toilet orientation must be faced north or south to respect the Qiblah as the direction of prayer. The ablution and shower area don't have any requirement to face any direction (Figure 1 and 2).

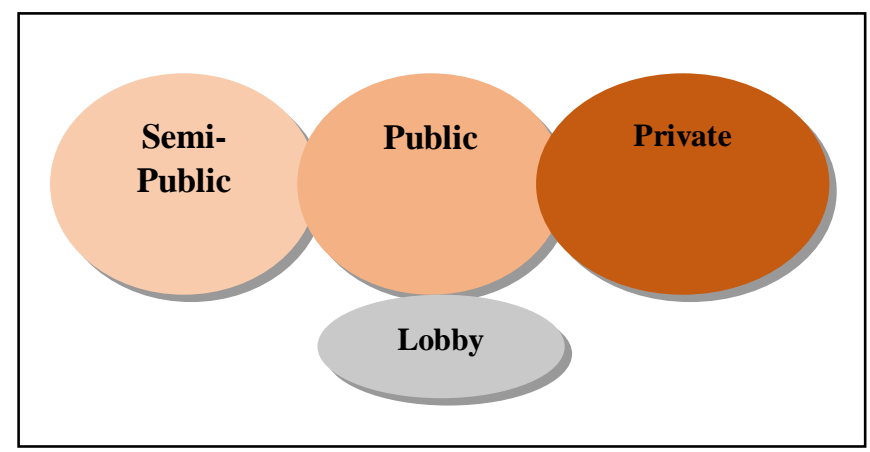

Figure 1. Zoning bubble diagram

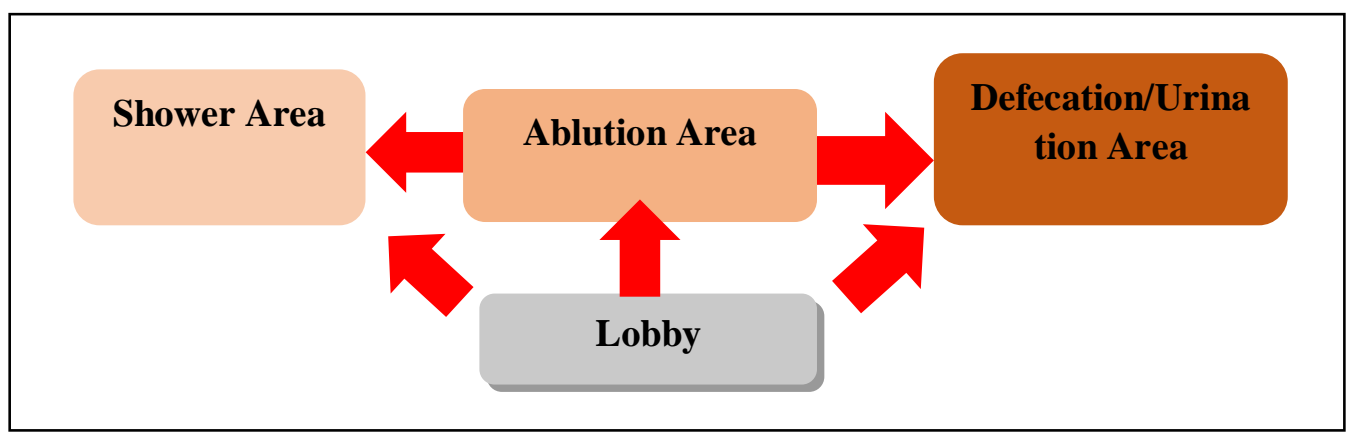

Figure 2. Areas in bathroom based on the zoning type

The floor level and walls can separate each area of the bathroom. In the bathroom with narrow space, the ablution and shower area can be merged because of the low impurity level in those areas, although it is better to separate them too, to prevent any impurity in the ablution area. The 
defecation/urination area is the most private in the bathroom with the lowest cleanliness level, so it should always closed / semi-closed visually from others.

The water source in Islamic bathroom must have a flowing water system as it is said in a Hadits, that the purest water is the water that flows. Showers and faucets are permittable, and so does water tub. Water tub is used differently than the bathtub. It must be used with the dipper to run off the water to all over the body. In performing Istinja, cleaning private part of the body after defecating/urinating, should use the water as well. Therefore, one can use the toilet-bidet system as the water source, or the bidet shower system. When using the bidet shower system, the placement of the shower is on the right side of the toilet, so the user can perform the Istinja with the right hand to push the bidet shower and use his left one to clean the private part. Each area in the bathroom is equipped with drain holes to ease the maintenance of cleaning. A bathroom is a place to perform self-cleansing. Therefore the cleanliness of it should be maintained as well. The slope of the floor should be set to allow the used water to flow to the drain hole fast.

The Bathtub is one of a bathroom fitting that allows the user to soak the body in the water and commonly would make the user take a longer time to bath. In Islam, lingering in the bathroom is not permitted, because it is useless and time wasting. In this journal, bathtub fitting doesn't recommend because of those reasons above. By the Hadits, there are researches said, squatting is the best way to relax the puborectalis muscle and straightens the rectum so that all the feces in the bowel can be released maximally, and so is the urine in the ureter. As a result of these researches, there is an awareness of the toilet designers to make a semi-squatting toilet and is recommended to use as an option in designing an Islamic bathroom (Figure 3and 4).

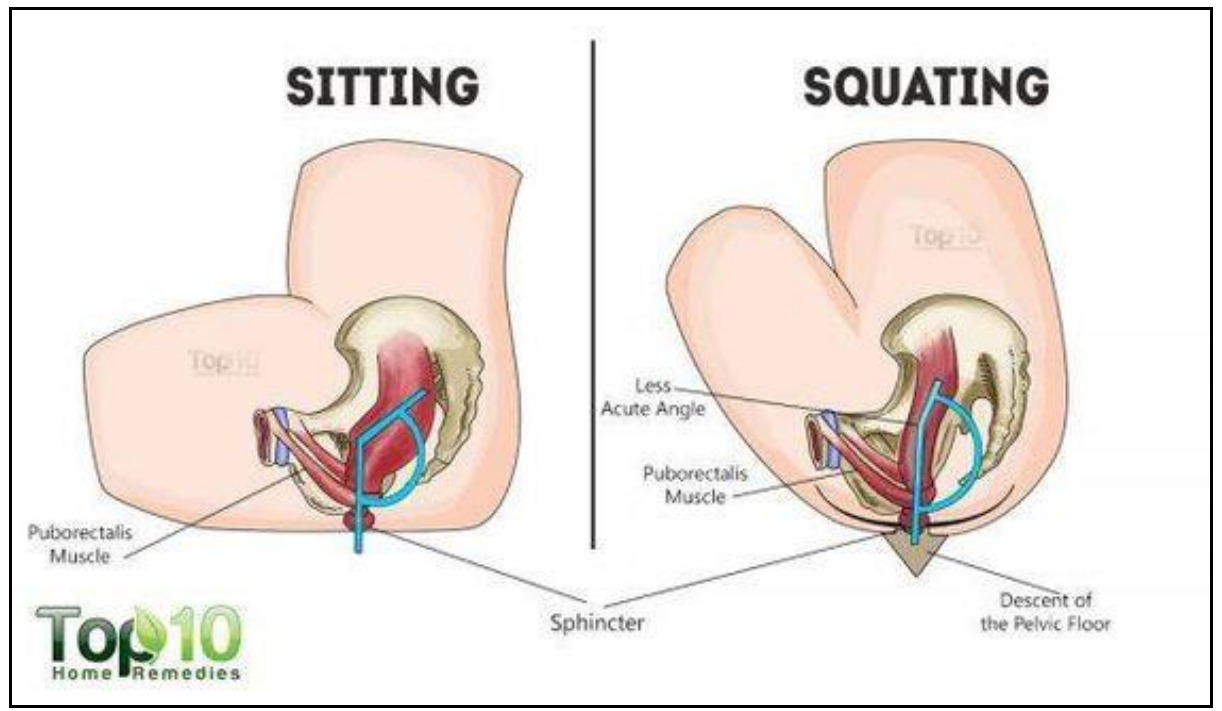

Figure 3. The difference between sitting and squatting (source: top10homeremedies.com) 


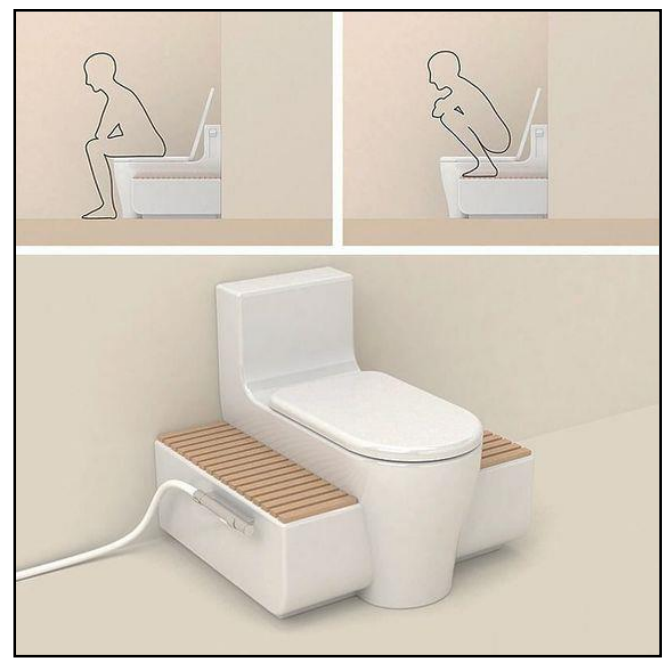

Figure 4. An example of a modern semi-squatting toilet design concept (source: WTO International Toilet Design Award, $1^{\text {st }}$ prize)

\section{Conclusion}

A family will use this recommendation. The location of the bathroom will be divided into two types, master bathroom, and bathroom between bedrooms with some detailed description (Table $5)$.

Table 5. The layout design recommendation

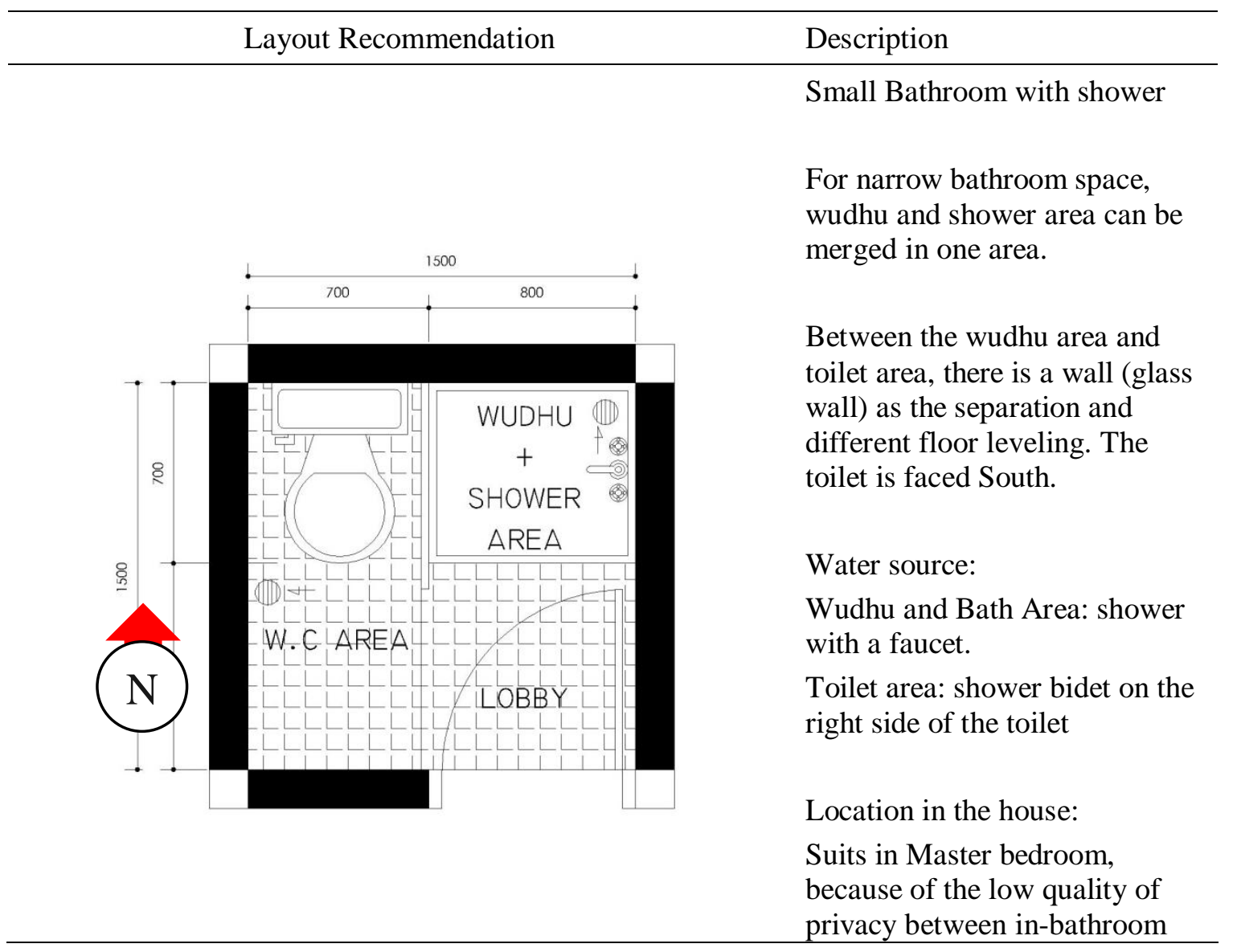


areas.

Lobby as a dry area

Medium Bathroom with shower

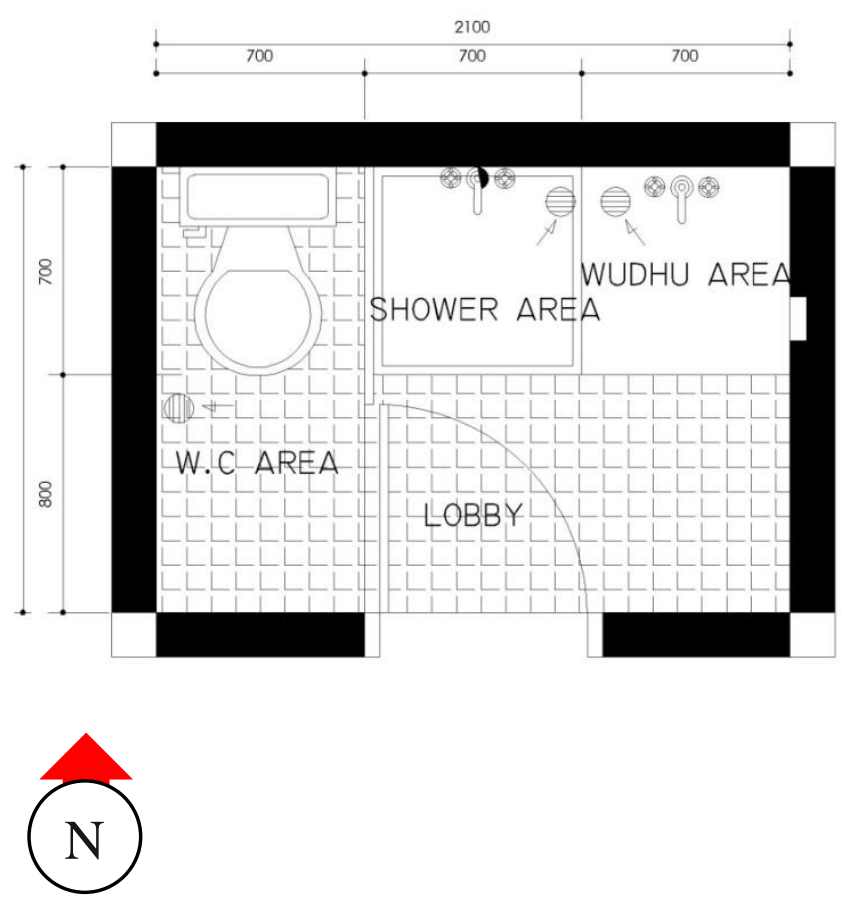

For a medium bathroom space, the wudhu and shower area would be better be separated by wall or glass, to prevent any impurity in ablution.

The placement of wudhu area is far from the toilet area. Whenever one has finished using the toilet, one can clean the feet and hands in the shower area to ensure there is no impurity attached. The toilet fitting is faced South.

Water source:

Wudhu area: faucet

Bath area: shower and faucet

Toilet area: shower bidet on the right side of the toilet

Lobby as a dry area

Location in the house:

Suits in the master bedroom or between bedrooms, because there is better separation between areas inside the bathroom so it can get better maintenance of cleanliness quality

Medium Bathroom with the water tub

The shower and wudhu area can use one single water tub as the source of clean water. The separation is set to get higher cleanliness level for the wudhu area.

The toilet is set far from the wudhu area, so one can clean his feet and hands in the shower area to ensure there is no impurity attached. The toilet is faced South. 

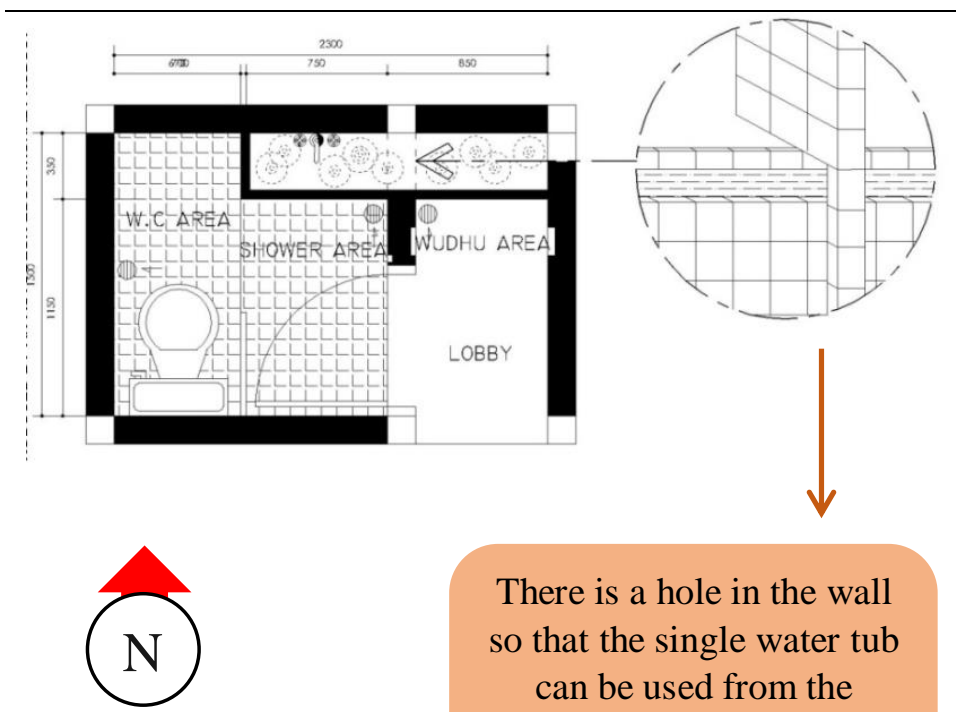

There is a hole in the wall so that the single water tub can be used from the shower area and wudhu area
Water source:

Wudhu area: a water tub

Bath area: a water tub

Toilet area: shower bidet on the right side of the toilet.

Location in the house:

Suits in the master bedroom or between bedrooms, because there is better separation between areas inside the bathroom so that it can get better maintenance of cleanliness quality

Lobby as a dry area

Large bathroom with shower

The lobby is set as a transition between each area. This layout is the best because the area with the lowest cleanliness level can be separated and get the highest privacy. For a family bathroom, the area can be used by different members at the same time.

Water source:

Wudhu area: a faucet

Bath area: a shower and a faucet

Toilet area: a shower bidet on the right side of the toilet

Location in the house:

Suits between bedrooms, because it has the best privacy system and can be used by different people at the same time. The cleanliness level also can be maintained better because of the clear separation of areas.

Lobby as a dry area 


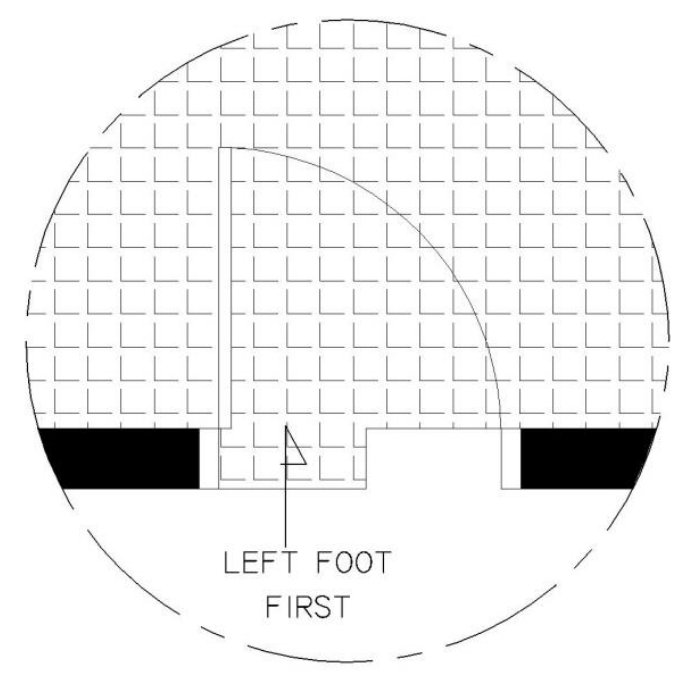

Features:

To prevent the user from forgetting to enter the bathroom with the left foot, the floor below the door can be set like the picture on the left. Therefore it necessitates the user to use the left foot first when entering the bathroom and use the right foot when exiting.

\section{Acknowledgment}

This research is funded by the Department of Architecture, Universitas Sumatera Utara as a reminder for the architects, that the universal design concept can't always fit in. Every human being has its different background with different needs, and so that the solution of the design should be different as well. The architects have to give harmony between the users' religion, especially the Muslims, and the design of their bathrooms.

\section{REFERENCES}

[1] Ernst \& Peter Neufert, Architets' Data, 3rd Editition.: Blackwell Science.

[2] Justin L. Barrett \& Roger Trigg, The Roots of Religion: Exploring the Cognitive Science of Religion. New York: Ashgate Publishing, 2014.

[3] Sunan An-Nasa'i, The Book of Purification, Book 1, Vol 1.

[4] At-Tirmidhi, The Book on Purification, Book 1, Vol 1.

[5] Al-Bukhari, The Book on Ablution, Book 4, Vol 1.

[6] Al-Bukhari, The Book on Dress, Book 77, Vol 1.

[7] Sunan Ibn Majah, The Book of Purification and Its Sunnah, Book 1, Vol 1.

[8] Muslim, The Book on Purification, Book 2, Hadits 65. 